\title{
Econometric Analysis of the Impact of Climate Change on the Sustainability of Agricultural Production in Ukraine
}

\author{
Andriy Skrypnyk', Oleksandr Zhemoyda ${ }^{2}$, Nataliia Klymenko ${ }^{1 *}$, \\ Liudmyla Galaieva' ${ }^{1}$, Tatiana Koval ${ }^{1}$ \\ 1 Department of Economic Cybernetics, National University of Life and Environmental Sciences of Ukraine, \\ Heroiv Oborony 16, 03041, Kyiv, Ukraine \\ 2 Ministry for Development of Economy, and Agriculture of Ukraine, Grushevskogo 12/2, 01008, Kyiv, Ukraine \\ * Corresponding author's email: nklimenko@nubip.edu.ua
}

\begin{abstract}
The aim of this paper was to determine the mechanisms of climate change impact on the yield of the main exportoriented crops in the agro-climatic zones of Ukraine. The study of the problem of changing the acreage of the main export-oriented crops was conducted according to the data of the State Statistics Service of Ukraine on the time horizon 2000-2018 in the following order: first, the dynamics of the change of the acreage under corn, sunflower and wheat by the agro-climatic zones of Ukraine was analyzed; secondly, the trends of yield changes of these crops were investigated based on the increase in the difference in yields between the northern and southern zones; and, finally, the temporal and spatial expansion in the area of crop propagation were investigated by applying the panel regression method. The findings obtained indicate that the applied models confirm the assumption of the effects of climate change on crop yield changes and the zones expansion in the northern direction. If the country's wheat area can be considered stable (variation is insignificant), then the corn and sunflower areas have grown steadily under the influence of increasing demand from national and world markets. At the same time, the growing acreage under corn and sunflower occurred in all climatic zones. Stable expansion of corn crops in the north direction in all three agroclimatic zones of Ukraine has been statistically confirmed. The article presents the findings of empirical analysis, which confirm that if the boundaries of soil and climatic zones change, the conditions of growing crops and their yield will consequently change as well. Thus, based on current global forecasts, the impact of weather on Ukraine's agriculture will increase, and the most negative effects can be expected in the Steppe zone, where the likelihood of weather and climate risks increases, requiring the development of adaptation and mitigation measures as well as exploitation of new potential opportunities that are being opened. Studies have shown that there is an expansion in crops to the north and a change in their pattern, including a significant increase in the area under corn.
\end{abstract}

Keywords: global climate change, acreage dynamics, climate change, modeling, crop patterns, crop acreage, panel regression, time series

\section{INTRODUCTION}

In recent years, scientists have advanced in the modeling of future climatic conditions, and have proven the fact of the area expansion of a number of crops cultivation in the northern direction due to climate change. This is resultant from the increase in the duration of the basic time interval when the temperature in the regions, being insufficient to grow some crops a few years ago, begins to steadily exceed the thresholds and the crop can to be successfully cultivated (IPCC, 2014). It should be emphasized that the climate change is not the only factor affecting the benefits of agricultural producers. A significant factor influencing the choice of crops is the level and dynamics of prices for agricultural products of the world and national food markets. It also takes into account the cost of purchasing the consumables of the production process.

The main factors that have a direct impact on the location and the area size of the cultivated 
crops are stable global population growth (Cohen, 1997), a shift in demand for agricultural products (as a result of changes in diet, and a shift in demand for raw materials for other sectors of the economy) and climate change, which has become extreme in recent decades.

Agriculture is particularly vulnerable to weather fluctuations and climate change. Therefore, nowadays it is necessary to think about solving the problems arising from these changes, as global warming is gaining momentum and, in some scenarios, the average annual global atmospheric temperature may increase significantly in the next hundred years, if the existing anthropogenic trends continue (Brechin 1, 2003 and World Economic Forum, 2018). In the face of such rapid climate change, the ability of agriculture to adapt quickly to the likely weather and climate change will be of great importance. On the basis of the research of (York et al., 2003; Chen et al., 2017) the fact that the climate change has a significant impact on the frequency and intensity of extreme weather conditions, leading to significant losses in the regions where they occur, has already been proven (Cogato et al., 2019).

As the development of the agrarian sector of the Ukrainian economy directly affects the standard of living of the population, it is extremely important to analyze the structural changes in the area of crops, their expansion in recent years, justification of the factors influencing these changes and forecasting the production of basic crops under these conditions (Kadiyevskyy and Klymenko, 2014; Voronenko et al., 2020).

Addressing these issues will help to make adequate decisions to develop a strategy for further performance increase of Ukraine's agriculture in the face of climate change.

\section{Literature review}

A number of studies by foreign and domestic scientists are devoted to the climate change impacts on the environment and human life, and in particular on agriculture. The works by (Kalenska et al., 2019) analyze the dynamics of weather changes of the Forest Steppe of Ukraine for the period of 2004-2017. Studies have confirmed a trend of an increase in air temperatures and decline in rainfall, which adversely affected the plant growth, development and productivity. The impact of climate change on crop yields, including corn, is described in the works by (Amadu et al., 2020). This concern was also raised in the works by (Asfaw et al., 2016; Coulibaly et al., 2017). Climate shocks and other changes threaten to further reduce the agricultural productivity across the continent (FAO, 2017; IPCC, 2018; Müller et al., 2011).

Improving soil nutrition and erosion control can lead to increased crop yields, as proven by research (Coulibaly et al., 2017; Kassie et al., 2015; Noltze et al., 2013). Climate risk management - CRM, has already been established. It is based on the usage of climate information in a multidisciplinary scientific approach to address the effects of climate change on development and resource management issues (Gobin et al., 2013; Siwiec, 2015).

Climate risk management covers a wide range of potential actions, including early response systems, strategic diversification, dynamic resource allocation rules, financial instruments, infrastructure design and capacity building. CRM is the use of climate information to address the potential effects of climate change on development and resource management (Selvaraju et al., 2011; Skrypnyk, 2019).

The works by (Report OCHA, 2019 and IPCC, 2014) indicated that in recent decades, the number and intensity of natural disasters that have affected North America, Central America and the Caribbean has increased, repeatedly demonstrating how vulnerable local agriculture is to extreme episodic events. With this in mind, it is to be expected that the frequency and intensity of some episodic events will increase with climate change and that risk management is increasingly important for farmers to assess the effects of extreme weather events caused by the climate change.

Some farmers in these regions are already applying different strategies to reduce the weather and climate risks as well as uncertainties, including diversification of agricultural businesses, diversification of crops and varieties, search for alternative sources of income, and insurance of weather crop risks (Tun Oo et al., 2017; Bokusheva, 2011; Shannon and Motha, 2015). The impact of extreme weather on the global agrarian sector is covered in the overview study by (Cogato et al., 2019). The overview study analyzes 19 major crop systems (cereals, legumes, viticulture, horticulture, gardening, pastures, etc.) across five continents and identifies major weather risks affecting each of these systems. A number of papers (Pace, 2015; Tesfahun, 2018) analyze the use of 
the existing genetic engineering and biotechnology techniques aimed at mitigating the impact of climate change on the agricultural sector.

The papers by the scientists (Passel et al., 2017; Ren and Lin, 2001) have shown both the positive and negative effects of the climate change on the planet and have proven that, first and foremost, the so-called "poor countries" will suffer from natural disasters and losses, since elimination of negative effects requires a lot of money. Developing countries do not have sufficient material resources to provide their population with even the necessary minimum in the event of natural disasters or the declining yields of major strategic crops under the influence of climate change, so food security is of paramount importance to them (Dittrich et al., 2016).

The rise of the carbon levels in the atmosphere, which, in particular, causes such global climate change on the planet, according to scientists, has both positive and negative consequences. It is substantiated that the increased carbon levels can accelerate the photosynthesis of some crops, such as wheat, rice and soybeans, but do not affect the development of such important crops as corn (Rosenzweig et al., 2001).

Thus, according to the research by scientists (Imelda et al., 2018; Shannon and Motha, 2015) the agricultural productivity in most southern regions of the United States is declining due to the global warming. The same situation has been investigated by European scientists (Passel et al., 2012), where studies of almost 40,000 farms in countries have shown that the farm returns in Southern Europe are declining and will decline by $8-13 \%$ when the temperature rises by 1 degree.

The challenges of providing food to the population of their country have always been important to China, so the following research (Xiong et al., 2012; Zhou et al., 2017) on the impact of global climate warming on crop yields (rice, wheat, corn and soybeans) showed a decrease in the yield of these crops on most arable land. Due to the effects of climate change in recent years, the wheat and corn production was declining annually by 120 and 212 thousand tons, respectively. At the same time, the rice and soybean production in China was increasing annually by an average of 320 and 70 thousand tons, respectively, during this period.

The fact that the agricultural sector of any country, including Ukraine, is vulnerable to extreme climatic conditions has been ascertained by scientists from all over the world (Morison,
1996; Rudych, 2018). On the basis of the research of Ukrainian scientists (Nechyporenko, 2016; Panasyuk, 2015; Adamenko,2013), the climate change (greenhouse effect, warming) has both positive and negative effects. In the course of the research, the negative effects were analyzed, as they are a challenge and need an urgent analysis.

As the winter period in the country decreased by almost a month, the sowing campaign starts 2 weeks earlier. The rainfall decreased, which affected the spread of droughts to the northern regions; in other regions, the number and intensity of floods and other cataclysms increased. Therefore, some authors (Rudych, 2018; Tsytsiura, 2017) believe that the agro-climatic zones of Ukraine have expanded $100-150 \mathrm{~km}$ to the north. Among the negative effects of climate change, scientists also highlight the increase in intensity and frequency of strong winds, which leads to wind erosion of soils, certain difficulties with the use of plant protection products, causing higher risk of an increase of the number of pests by 1.5 2 times (Didukh, 2009).

A change in the duration of the growing season of crops is becoming a serious problem for the country. For the northern regions of Ukraine, the rise in the average annual air temperature by $1-2^{\circ} \mathrm{C}$ is a positive factor, and the southern regions may become unsuitable for agriculture due to increased drought events. On the basis of the research (Prokopenko and Udova, 2017) conducted over the past twenty-five years, the average air temperature in Ukraine has increased by about $1.5^{\circ} \mathrm{C}$, indicating very rapid climatic processes, which are confirmed by the world statistics (IPCC, 2018)

Scientific research (Tsytsiura, 2017) proved that the following steps are necessary for efficient agriculture: to accelerate the adaptation of crop production to these changes by introducing sustainable varieties and zoning of new crops, to introduce the systems of agriculture with high soil protection and moisture-preserving qualities, to adjust the farming systems and technologies to meet the challenges and mechanisms of crop insurance against adverse natural conditions.

The main global instruments, which define the global directions for climate change adaptation and which the Government of Ukraine is currently governed by, are the UN Framework Convention on Climate Change and the Paris Agreement - ratified in 2016 (will enter into force after 2020), the analysis of which shows intentions to 
develop international climate change policy (Ollila, 2019; Lal Pandey, 2014).

Agricultural plants respond differently to the increasing carbon dioxide content in the atmosphere and are divided into two groups: (1) plants with high sensitivity to carbon dioxide concentration (C3 plants) - wheat, barley, sunflower, rice and soy are included in this group; (2) plants with low sensitivity to carbon dioxide increase ( $\mathrm{C} 4$ plants) - they include corn, sorghum, and sugar beet. C4 crop yields, with increasing carbon dioxide concentrations, should decrease substantially, but at present, the change in heat regime has a positive effect on corn yields. The increase in the average annual air temperature contributed to the expansion of acreage under the uncharacteristic for the zone of the Forest Steppe crop - corn and its successful cultivation in the west and north of Ukraine.

Climate warming in Ukraine generally has a positive effect on crop productivity. On the basis of scientific research (Nechyporenko, 2016; Tsytsiura, 2017; Rudych, 2018) provided being well-watered, the increase of winter wheat yield is expected (including the Forest Steppe zone up to $10-15 \%$, for the Steppe and Mixed Forest zone (Polissya) - up to 20-30\%), as well as for the whole grain crops in all agro-climatic zones of Ukraine. It is expected that winter and spring wheat, barley, rice, soybeans will grow better, their maturation will accelerate, and the yield will increase by $20-30 \%$.

Sunflower absorbs more water from the soil than grain crops (winter wheat or corn). The minimum requirement of crop in water is $350-400$ $\mathrm{mm}$ of rainfall, and the minimum sum of effective temperatures for early varieties and hybrids should reach $1450^{\circ} \mathrm{C}$, for average ones $-1600^{\circ} \mathrm{C}$.

However, it was proven scientifically that in the absence of the measures aimed at the adaptation of these changes in the southern regions of Ukraine, we may witness the crop yields reduced by 10 to $20 \%$ and more by 2050 .

\section{RESULTS AND DISCUSSION}

The recognition of the climate change on the territory of Ukraine can already be considered as a proven fact. According to the observations of the Ukrainian Hydrometeorological Center, the average annual temperature in the territory of Ukraine between 1972 and 2017 increased by 1.7 degrees Celsius. The estimation was performed using a linear trend model and found that the hypothesis $H_{0}$ (no increase in average annual temperature) should be rejected at an extremely low level of significance, and the growth rate was approximately 0.47 degrees Celsius over a decade

\section{The dynamics of major crop areas}

In the course of the study, the impact of these climate changes on the indicators of agrarian production of Ukraine was analyzed according to data of the State Statistics Service of Ukraine (SSC, 2018) on the acreage of individual crops in the context of regions of Ukraine from 2000 to 2018. The studies were conducted for traditional crops such as sunflower, corn and wheat. In total, these crops occupy about $50 \%$ of the agricultural land. It should be emphasized that Figure 1 shows the information on the areas from which crops are harvested. Therefore, the influence of weather risks is added to the random factor of crop selection. This explains the fact that the areas under wheat remained in the range of 5-7 million hectares during 2000-2018, except in 2003, when they decreased to 2 million hectares due to the winter kill of winter crops in spring (Figure 1).

The situation with the cultivation of corn and sunflower is different: the areas under corn have increased within the time interval of the study from 1 to 4.5 million hectares, under sunflower from 3 to 6.4 million hectares. Research has shown that the process of sunflower and corn areas expansion is fully in line with the growing demand for these crops on the domestic and global food markets, and therefore the area distribution achieved by 2018 is likely to remain with small fluctuations. The total area of arable land in each zone and indicators of its variation are presented in Table 1.

The largest area is occupied by the natural and climatic zone of the Steppe $-47.7 \%$, followed by the Forest Steppe $-35.2 \%$, whereas the smallest one is Mixed Forest (Polissya) - 17.1\%. The data for 2003 were excluded from consideration (replaced by the 2002-2004 average), being an extreme phenomenon, in order to assess the magnitude of agro-climatic risks more objectively. The variability of arable land in all three zones of Ukraine is insignificant; the highest coefficient of variation for Forest Steppe does not exceed $5.2 \%$. According to the average crop areas and production volumes, the three crops under study are Ukraine's main export-oriented crops; they 


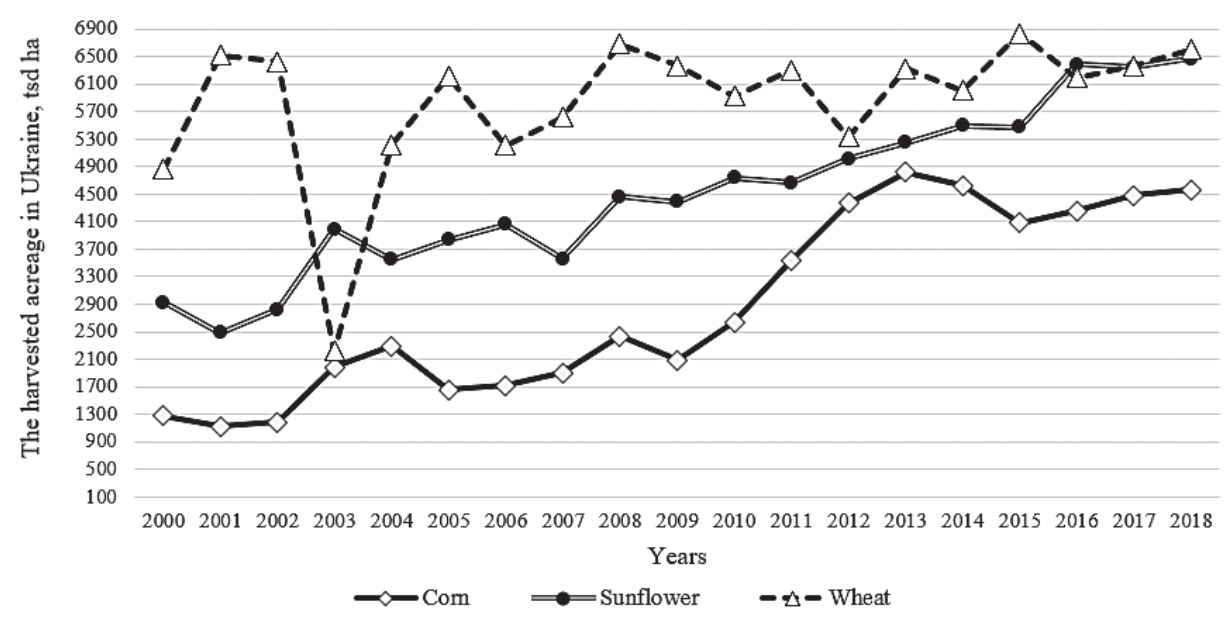

Fig. 1. The dynamics of area changes under corn, sunflower and wheat in Ukraine

Table 1. Average arable areas by the agro-climatic zones of Ukraine on the horizon 2000-2018

\begin{tabular}{|l|c|c|c|c|}
\hline Agro-climatic zone & $\begin{array}{c}\text { The average areas of arable land } \\
\text { (except for the extreme 2003), mln ha }\end{array}$ & $\begin{array}{c}\text { The standard } \\
\text { deviation }\end{array}$ & $\begin{array}{c}\text { Variation } \\
\text { coefficient, \% }\end{array}$ & $\begin{array}{c}\text { The total area of } \\
\text { crops in Ukraine, \% }\end{array}$ \\
\hline Steppe & 13.81 & 0.32 & 2.3 & 47.7 \\
\hline Forest Steppe & 10.20 & 0.53 & 5.2 & 35.2 \\
\hline Polissya & 4.95 & 0.18 & 3.6 & 17.1 \\
\hline Ukraine as a whole & 28.96 & 0.9 & 3.1 & 100 \\
\hline
\end{tabular}

cover approximately 17 million hectares, which is $59.4 \%$ of the total arable land in Ukraine.

\section{The dynamics of agricultural areas by the agro-climatic zones}

Figures 2, 3, and 4 analyze the areas of crops by the agro-climatic zones of Ukraine (Steppe, Forest Steppe, Polissya). As for the traditional wheat crop for Ukraine, it is characterized by the absence of any tendencies - the dynamics of the areas from which the crop is harvested is shown in Figure 2. An exception is the case in 2003, when more than 3 million hectares of wheat crops in the Steppe and Forest Steppe zones were not harvested due to the winter kill of winter wheat crops in the spring of the same year.

This is a clear example of weather risk manifestations, which was realized in the loss of approximately $30-40 \%$ of the area of wheat crops. The highest absolute and relative variability of the areas is observed in the Steppe zone - the coefficient of variation is $13.6 \%$, the lowest in Polissya, where the share of arable land under wheat is the lowest $-15.8 \%$, but the variability of these areas is also the lowest $-5.8 \%$ (Table 2 ).

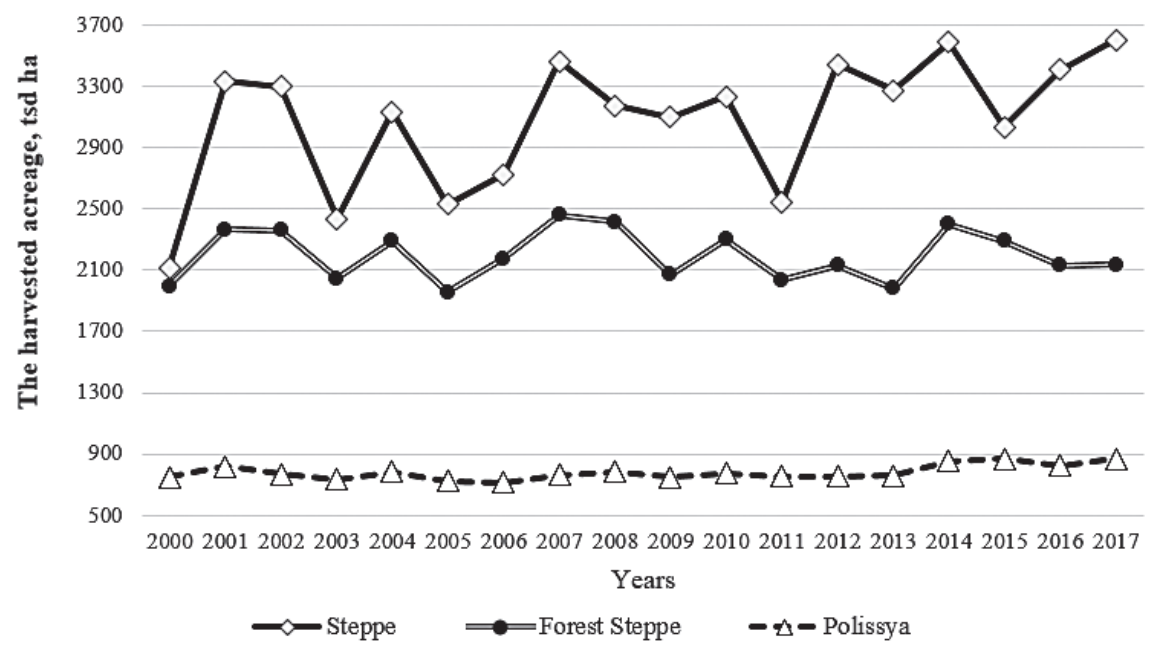

Fig. 2. The dynamics of the wheat areas change by the agro-climatic zones of Ukraine, thousand ha 
Table 2. Average wheat areas by the agro-climatic zones of Ukraine on the horizon 2000-2018

\begin{tabular}{|l|c|c|c|c|}
\hline Agro-climatic zone & $\begin{array}{c}\text { Average areas of wheat (except } \\
\text { for extreme 2003), mln ha }\end{array}$ & $\begin{array}{c}\text { The standard } \\
\text { deviation }\end{array}$ & $\begin{array}{c}\text { Variation } \\
\text { coefficient, \% }\end{array}$ & $\begin{array}{c}\text { The total area of } \\
\text { crops in the zone, \% }\end{array}$ \\
\hline Steppe & 3.08 & 0.42 & 13.6 & 22.3 \\
\hline Forest Steppe & 2.20 & 0.16 & 7.3 & 21.6 \\
\hline Polissya & 0.78 & 0.05 & 5.8 & 15.8 \\
\hline Ukraine as a whole & 6.06 & - & - & 20.9 \\
\hline
\end{tabular}

Another picture is observed for corn and sunflower (Fig. 3, 4). Most likely, the dynamics that follow are explained by the demand from both the global and national food markets.

As shown in Figure 3, the Forest Steppe zone has witnessed an increase in the corn areas from 0.5 to 2.5 million hectares in recent years. This trend is also traced in the Polissya area (increase from 0.1 to 0.8 million hectares). It should be emphasized that the overall macroeconomic situation in the country is reflected in the change of corn crops. This may be due to the neglect of the share of crops located in the occupied territories of Donetsk, Luhansk and Crimea, but most likely due to the current situation in the country and, quite possibly, the general downturn observed after the Russian aggression in 2014.

However, these trends are practically not reflected on the sunflower crops (Figure 4), where a steady increase in the area in the Steppe and Forest Steppe zone is noted.

This trend may be also traced in the Polissya zone, as the area under sunflower has increased from $0.1 \mathrm{mln} 0.7 \mathrm{mln}$ ha.

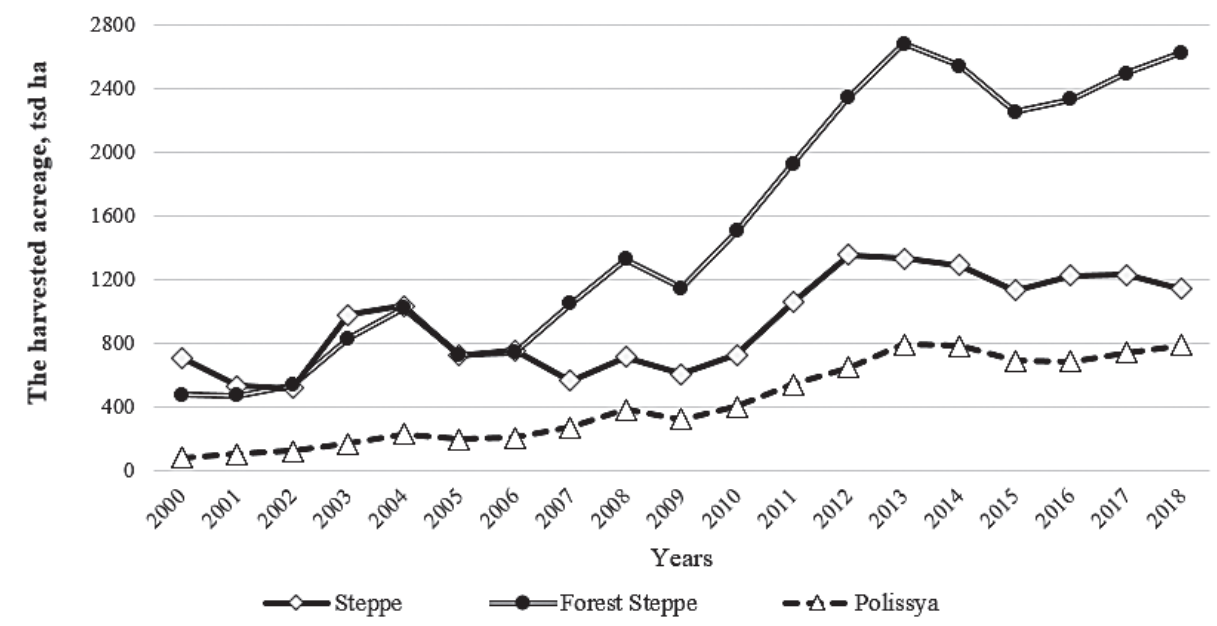

Fig. 3. The dynamics of the corn areas change by the agro-climatic zones of Ukraine, thousand ha

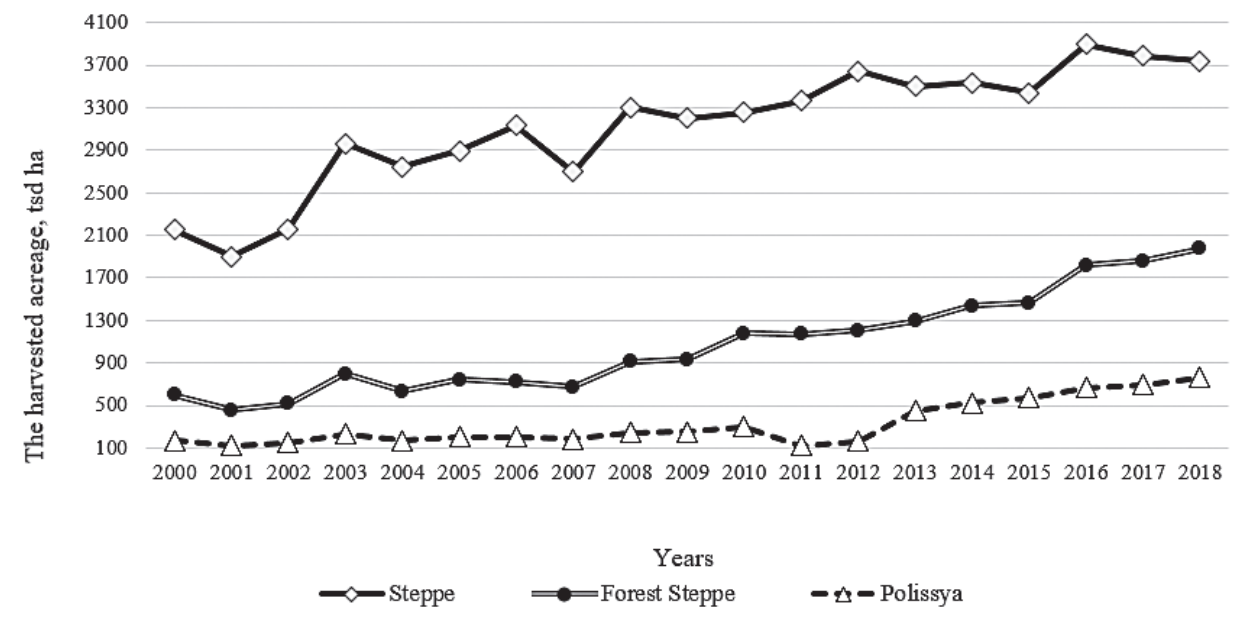

Fig. 4. The dynamics of the sunflower areas change by the agro-climatic zones of Ukraine, thousand ha [Based on (SSC, 2018), own calculations] 


\section{Yield factor as a cause of change of crop area under individual crops in different agro-climatic zones}

The wheat yield is characterized by growth in all three zones, which is subject to fluctuations caused by weather factors, which are practically synchronous in all agro-climatic zones of Ukraine (Figure 5). Weather risks fully emerged in 2003, when the yields in the Steppe zone went beyond the confidence threshold, which was considered a serious threat to food security and further facilitated the quotas for agriculture. As for the corn (Figure 6) and sunflower (Figure 7) yield, an increase in the yield figures is observed, being significantly higher for the Forest Steppe and Polissya than for the Steppe zone.
For almost all crops considered, the highest yield was observed in the Forest Steppe zone, but the average Polissya yields are better than the Steppe yields in the 2000-2018 time interval. The estimates of the mathematical expectation and variation of yield of the studied crops by the agroclimatic zones of Ukraine are given in Table 3.

\section{Test of assumption about the significance of crop yield differences in the Forest Steppe and Steppe zones}

Using the Student's t-criterion, we analyze the assumption that the average yield of the Forest Steppe exceeds that of the Steppe zone. Let us estimate the significance of the difference between the average yields in the Steppe and the Forest Steppe zones:

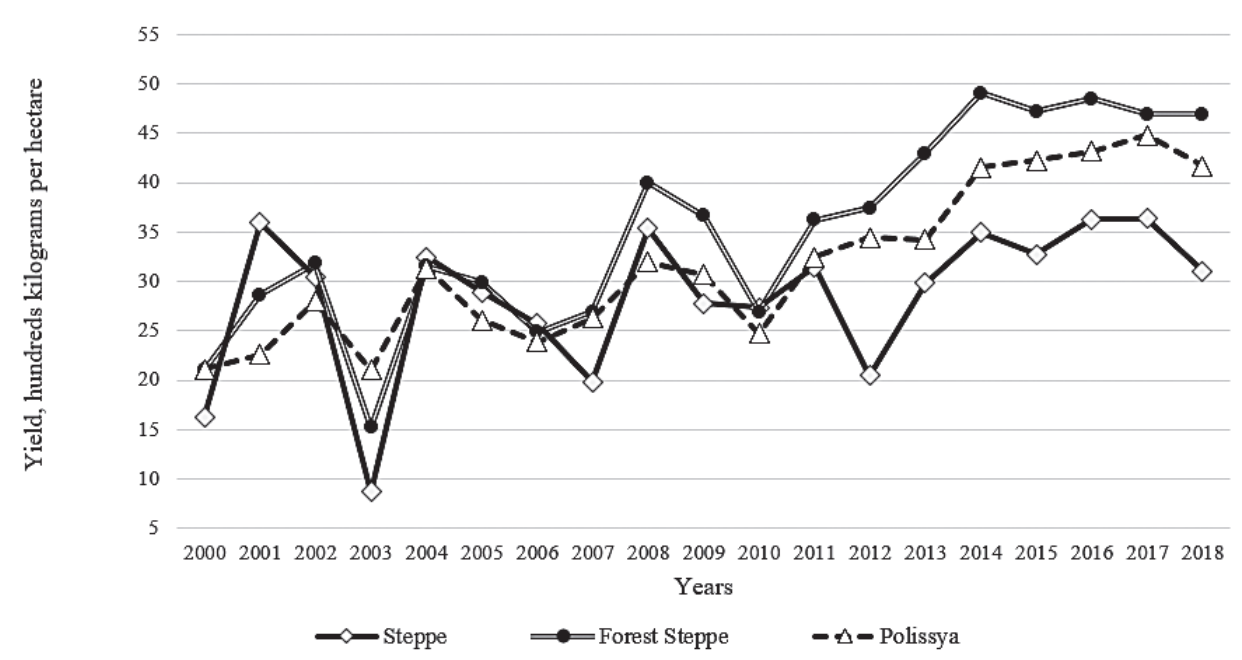

Fig. 5. The dynamics of average wheat yields by the agro-climatic zones of Ukraine in the 2000-2018 time interval

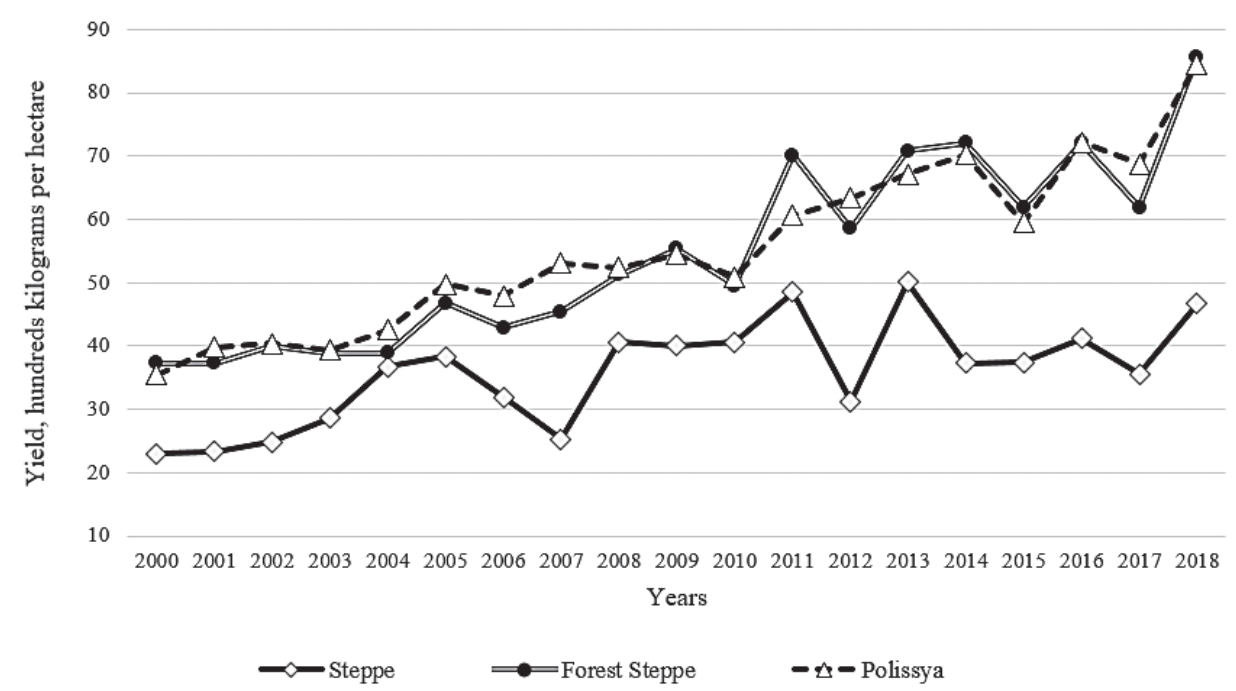

Fig. 6. The dynamics of average corn yields by the agro-climatic zones of Ukraine in the 2000-2018 time interval 


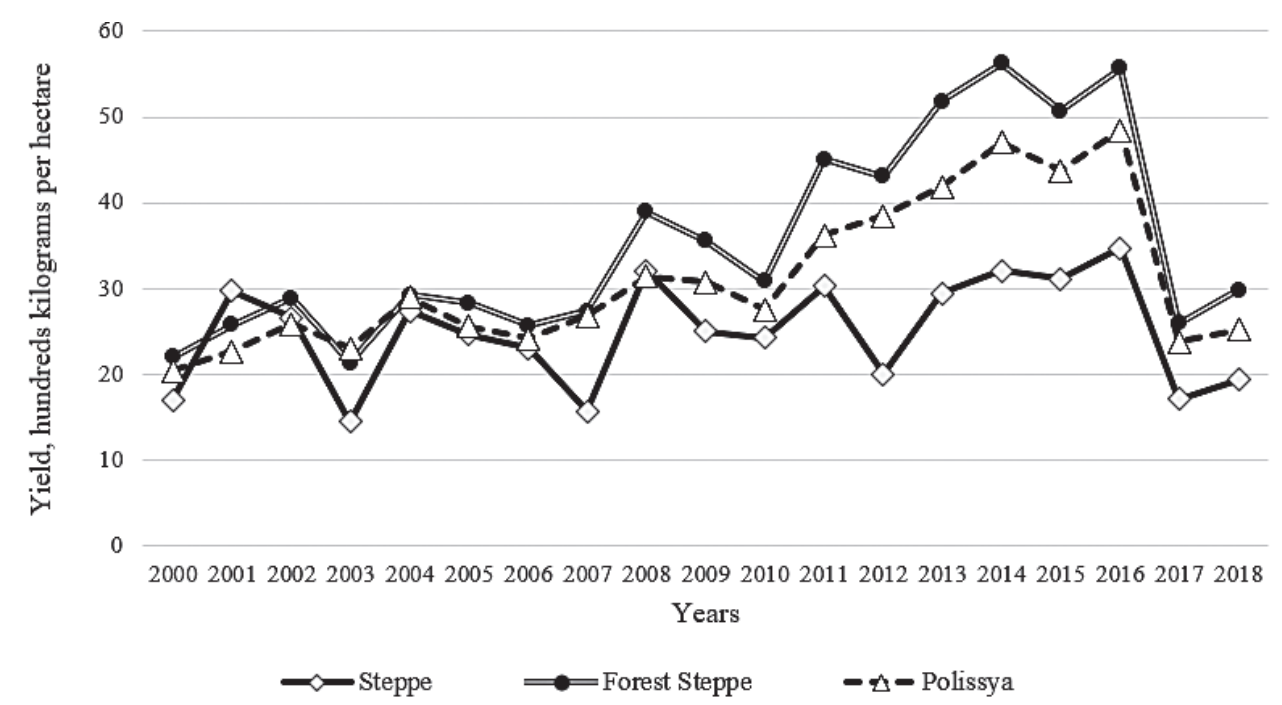

Fig. 7. The dynamics of average sunflower yields by the agro-climatic zones of Ukraine in the 2000-2018 time interval

Table 3. Statistical estimates of the yield of the studied crops by agro-climatic zones of Ukraine on the horizon 2000-2018

\begin{tabular}{|l|c|c|c|c|c|c|}
\hline \multirow{3}{*}{ Crop } & \multicolumn{6}{|c|}{ Agro-climatic zones of Ukraine } \\
\cline { 2 - 7 } & \multicolumn{3}{|c|}{ Steppe } & \multicolumn{2}{c|}{ Forest Steppe } & \multicolumn{2}{c|}{ Polissya } \\
\cline { 2 - 7 } & \multicolumn{7}{|c|}{ Statistical estimates of crop yields } \\
\cline { 2 - 7 } & $\begin{array}{c}\text { Average, } \\
\text { hundreds, kg/ha }\end{array}$ & $\begin{array}{c}\text { Standard deviation } \\
\text { (mean accuracy) }\end{array}$ & $\begin{array}{c}\text { Average, } \\
\text { hundreds, kg/ha }\end{array}$ & $\begin{array}{c}\text { Standard deviation } \\
\text { (mean accuracy) }\end{array}$ & $\begin{array}{c}\text { Average, } \\
\text { hundreds, kg/ha }\end{array}$ & $\begin{array}{c}\text { Standard deviation } \\
\text { (mean accuracy) }\end{array}$ \\
\hline Wheat & 28.5 & $7.5(1.7)$ & 35.2 & $10.1(2.3)$ & 31.7 & $7.9(1.8)$ \\
\hline Corn & 35.9 & $8.2(1.9)$ & 54.6 & $14.6(3.3)$ & 55.4 & $13.3(3.1)$ \\
\hline Sunflower & 25.0 & $6.2(1.4)$ & 35.4 & $11.6(2.7)$ & 31.2 & $8.8(2.0)$ \\
\hline
\end{tabular}

$$
t=\frac{\bar{y}_{L}-\bar{y}_{S}}{\sqrt{\frac{\sigma_{p}^{2}}{n_{L}}+\frac{\sigma_{p}^{2}}{n_{S}}}} ; \sigma_{p}^{2}=\frac{\left(n_{L}-1\right) \sigma_{L}^{2}+\left(n_{S}-1\right) \sigma_{S}^{2}}{n_{L}+n_{S}-2}
$$

where: $\bar{y}_{L}, \bar{y}_{S}-$ average yields of Forest Steppe and Steppe;

$\sigma_{L}^{2} ; \sigma_{S}^{2}-$ yields dispersion in the Forest Steppe and Steppe zones;

$n_{L}, n_{S}-$ number of observations (years)

in the Forest Steppe and Steppe.

Estimates of $t$ statistics for three crops:

$$
t_{w}=2.2 ; t_{c}=4.7 ; t_{s}=6.7
$$

where: $t_{w}-$ wheat; $t_{c}-$ corn; $t_{s}-$ sunflower.

For all three crops, the excess of yield in the Forest Steppe zone in relation to the Steppe zone is statistically significant, the highest level of significance (error probability of rejection of hypothesis regarding the same yield in the Forest Steppe and Steppe zones) is 0.05 for wheat; for corn and sunflower, it is less than 0.0001 . This demonstrates an extremely sustainable stability of crop yields in the Forest Steppe zone compared to the Steppe zone.

A similar situation is observed if we compare the yields in the Steppe and Polissya areas (the yields in the Polissya area are much higher). The study thoroughly analyzed the characteristics of this process. For this purpose, the yield differences of these crops for the Forest Steppe and Steppe zones were analyzed. The trend dependence of differences on time $t$ (Figure 8) was constructed based on the obtained differences of yields:

$$
\Delta \mathrm{y}(\mathrm{t})=\beta_{0}+\beta_{1} t+\varepsilon
$$

The $\beta_{0}$ coefficient characterizes the timeless differentiation of the Forest Steppe and Steppe yields, the $\beta_{1}$ coefficient - its dynamic component, $\varepsilon$ - an error that is determined by the variability of weather conditions in these zones and is characterized by a standard error (Table 4).

The adequacy parameters of the proposed models indicate that approximately $50-60 \%$ of 


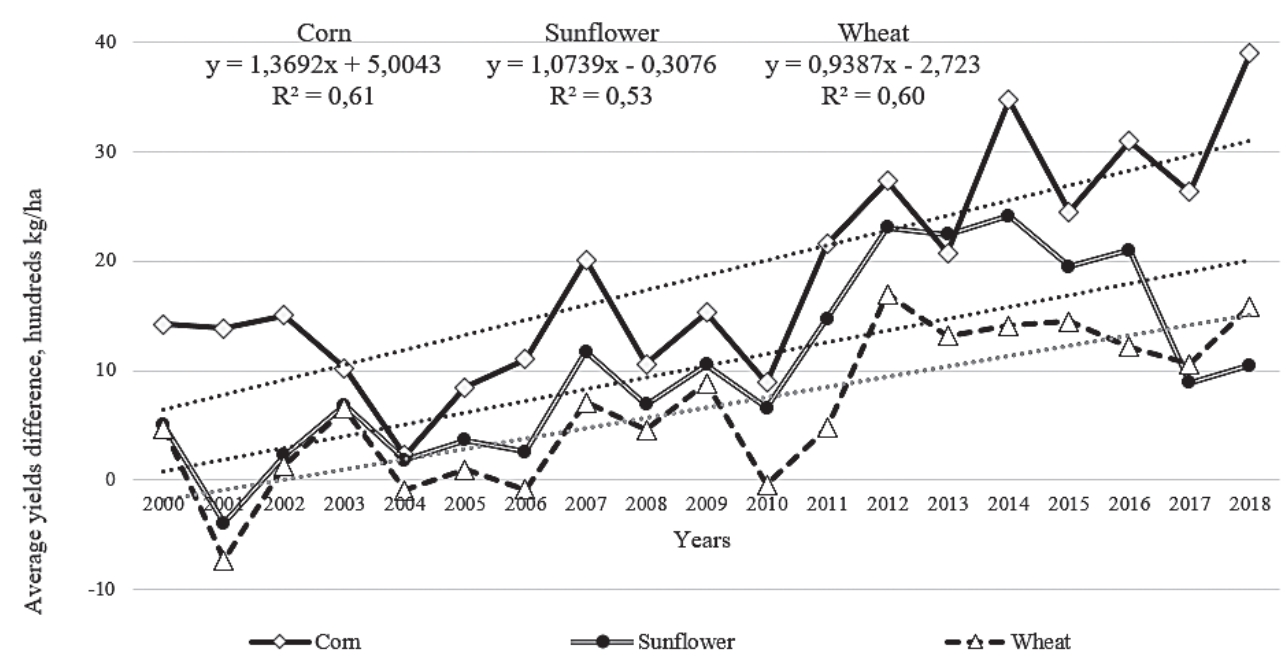

Fig. 8. The dynamics of the yield differences of the Forest Steppe and Steppe for corn, wheat and sunflower

Table 4. Statistical estimates of trends in the crop productivity differences between Forest Steppe and Steppe zones

\begin{tabular}{|l|c|c|c|c|c|}
\hline \multicolumn{1}{|c|}{ Crop } & $\begin{array}{c}\text { Timeless differentiation, } \\
\hat{\beta}_{0}\end{array}$ & $\begin{array}{c}\mathrm{t} \text {-criterion } \\
\text { (confidence level) }\end{array}$ & $\begin{array}{c}\mathrm{R}^{2} \\
(\%)\end{array}$ & $\begin{array}{c}\text { Annual growth rate } \\
\hat{\beta}_{1}\end{array}$ & $\begin{array}{c}\mathrm{t} \text {-criterion } \\
\text { (confidence level) }\end{array}$ \\
\hline Wheat & -2.7 & $-1.6(0.2)$ & 60 & 0.94 & $5.1(0.0001)$ \\
\hline Corn & 5.0 & $1.8(0.09)$ & 62 & 1.3 & $4.0(0.001)$ \\
\hline Sunflower & -0.3 & $0.1(0.9)$ & 53 & 1.1 & $4.4(0.0004)$ \\
\hline
\end{tabular}

the variance in yield differences by individual agro-climatic zone is explained by the linear trend model, i.e. this difference increases with time. In order to explain this fact, the hypothesis was suggested that the southern areas will, over time, increasingly lack moisture as a result of the temperature background increase [needs to be confirmed].

For the studied crops, there is a growing difference in yields in the Forest Steppe and Steppe zones. All the coefficients that determine the annual rate of increase of the yield difference - positive and significant, i.e. $H_{0}$ (null hypothesis - lack of difference), are rejected at low level of significance (Table 4).

As for the timeless factor, it is determined by the significant difference in the yields of wheat (in favor of the Steppe) and corn (in favor of the Forest Steppe). However, over time, the impact of the timeless factor diminishes as a result of the steady dynamics of growing yield differences in favor of the Forest Steppe.

As part of the study, it was proven that the increase of the average annual temperature in the territory of Ukraine, which was discussed earlier, is the main reason for the positive dynamics of the growth of the productivity difference between the northern and southern zones.

\section{Testing the hypothesis regarding the areals change in agricultural crops growing}

The next stage of the research was to analyze the presence of the areals change in individual crops distribution in each climatic zone. For this purpose, the concept of the average latitude of the natural climate zone for each of the crops was used. It is defined as the average weighted latitude of regional centers pertaining to a given natural climate zone with weights equal to the ratio of the area of a certain crop in a given region to the total area of the crop in the climate zone:

$$
\varphi_{i j}=\frac{\sum_{k j=1}^{n j} S_{i j k} \varphi_{k j}}{\sum_{k j=1}^{n j} S_{i j k}}
$$

where: $i=1,2,3$-index of the number of crops, $j=1,2,3$-index of the agro-climatic zone, $k_{j}=1,2, \ldots n_{j}$-index of $k$-region in $j$-zone, $n_{j}$ - number of regions in $j$-agro-climatic zone.

The weighted average latitude for each crop under study and each natural and climatic zone was estimated at a time interval of 2000-2018. 
The time series of the weighted latitudes of each crop in each natural and climatic zone were based on the statistical models for checking the presence of crop change within the zones (Table 5).

On the basis of the study findings, a stable picture is not observed for any crop except corn. For example, for sunflower there is an expansion in the Forest Steppe and Steppe zones in the south direction. Thus, the presence of corn crop expansion within all three climate zones is substantiated. On the other hand, an attempt to analyze the off-zone expansion of crops was implemented using a panel regression apparatus. Econometrics considers either the analysis of long time series with the purpose of revealing the impact of the introduction of innovative technologies on the development of agrarian business, or the spatial analysis, such as the effectiveness of different forms of agrarian business on an annual time interval. At the same time, panel regression allowed us to simultaneously analyze the spatial heterogeneities that change over time.

The hypothesis regarding the northward expansion of the corn crop was tested using two options of panel regression:

- by analyzing the change of area in different agro-climatic zones of Ukraine,

- by changing the areas of the studied crops in individual regions.

In order to substantiate the impact of climate change on the distribution of areas under certain crops, the dynamics of changes in the area of these crops in the context of three natural and climatic zones of Ukraine (the Steppe, Forest Steppe, Polissya) was investigated.
For this purpose, a regression model was constructed for the areas of each crop (dependent variable), the inputs of which are the weighted average latitude indicator of the natural climate zone $x$, the time indicator $(t=1,2, \ldots, 18) p$, and their product $z=p \cdot x$, which is responsible for expansion of the crop northward. The corresponding agro-climatic zones (Steppe, Forest Steppe, Polissya) are indicated by the index $i,(i=1,2,3)$.

The planting acreage $y_{i t}$ for each of three crops, in i zone for the time period $t$ is denoted by:

$$
y_{i t}=\alpha_{i}+\beta^{T} x_{i t}+\varepsilon_{i t}
$$

where: $\alpha_{3}$ - local effect (zone, region effect),

$\beta-$ a vector representation of the regression coefficients for the inputs given by the matrix $x_{i t}$,

$\varepsilon_{i t}-$ model error, which varies depending on the zone and time.

The model was used for each crop. An indicator of the crop expansion in the north direction was the presence of a positive and significant coefficient at $z$. In the case of the first option of the studies (in the context of agroclimatic zones), it was found that the number of spatiotemporal observations (57) is insufficient, which made it impossible to obtain an adequate solution. In the case of area utilization by regions, the number of spatiotemporal observations (data from 24 regions over 19 years) was 456 , which was sufficient to construct a panel regression. As a result of the simulation, the presence of inter-regional expansion of the area of crops in the northern direction for Ukraine was confirmed for corn (Figure 9).

Table 5. Statistical estimations of trend models of crop yield change by agro-climatic zones of Ukraine

\begin{tabular}{|l|c|c|c|c|c|c|c|}
\hline \multicolumn{1}{|c|}{ Trend name } & $\mathrm{R}^{2}$ & $\begin{array}{c}\text { Standard error } \\
\text { of the model }\end{array}$ & $\mathrm{B}_{1}$ & Standard error $\mathrm{B}_{1}$ & t-statistics & p-value \\
\hline \multicolumn{7}{|c|}{ Sunflower } \\
\hline Steppe & 0.146 & 0.036 & -0.0026 & 0.0015 & 1.71 & 0.10 \\
\hline Forest Steppe & 0.263 & 0.026 & -0.0027 & 0.0011 & 2.46 & 0.02 \\
\hline Polissya & 0.239 & 0.210 & 0.0204 & 0.0088 & 2.31 & 0.03 \\
\hline \multicolumn{7}{|c|}{ Corn } \\
\hline Steppe & 0.262 & 0.111 & 0.0114 & 0.0047 & 2.45 & 0.03 \\
\hline Forest Steppe & 0.797 & 0.044 & 0.0151 & 0.0018 & 8.17 & $2.7 \mathrm{E}-07$ \\
\hline Polissya & 0.564 & 0.255 & 0.0503 & 0.0107 & 4.69 & 0.0002 \\
\hline \multicolumn{7}{|l|}{ Wheat } \\
\hline Steppe & 0.185 & 0.066 & 0.0055 & 0.0027 & 1.97 & 0.067 \\
\hline Forest Steppe & 0.868 & 0.025 & 0.0112 & 0.0010 & 10.57 & $6.9 \mathrm{E}-09$ \\
\hline Polissya & 0.089 & 0.076 & 0.0041 & 0.0032 & 1.29 & 0.2 \\
\hline
\end{tabular}




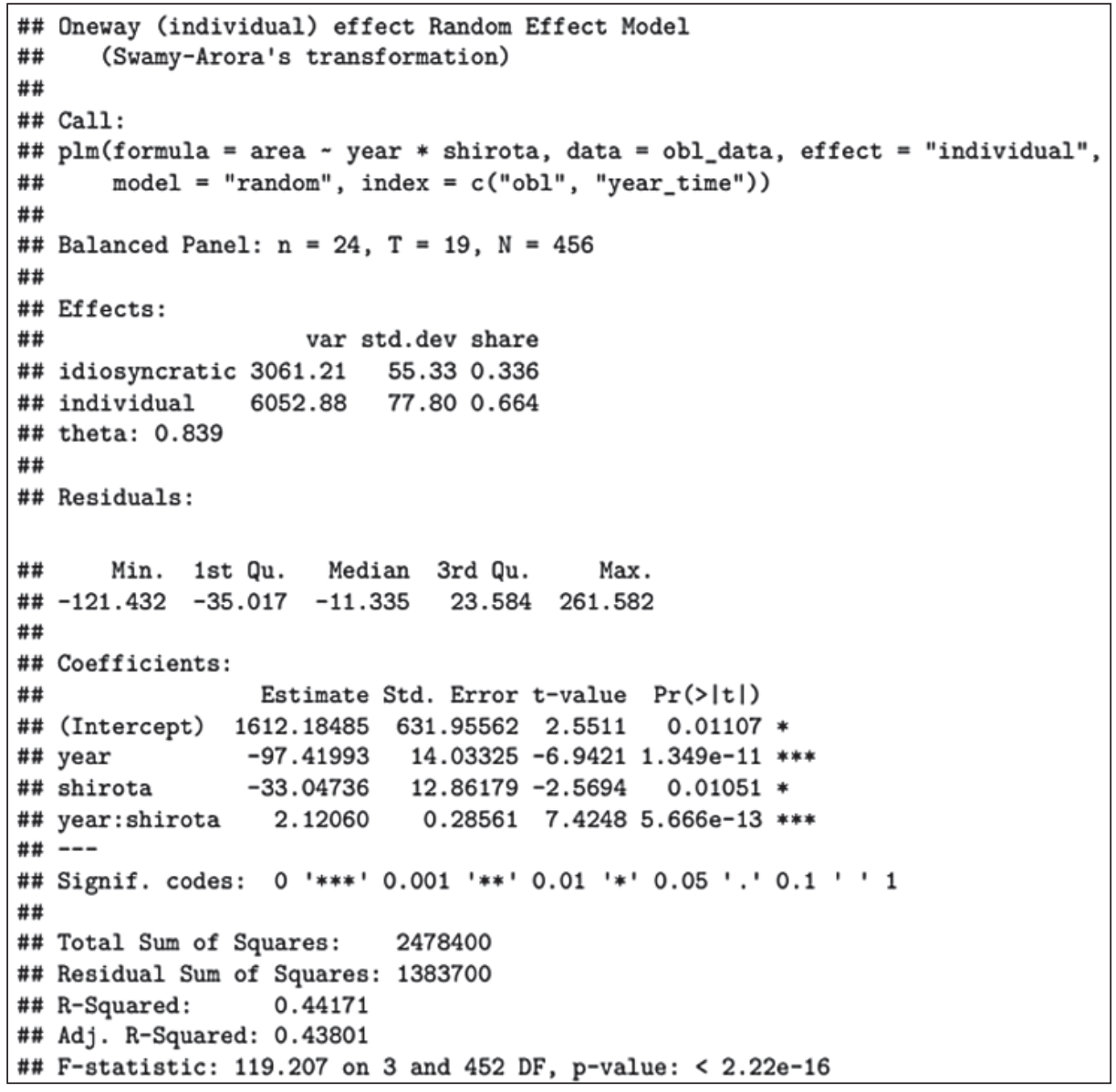

Figure 9. Results of panel regression calculations by regions

Although this regression model accounts for only $44 \%$ of the variance, the null hypothesis regarding the coefficient at the production of latitude by time $(z)$ is rejected at an extremely low level of significance, which indicates that the hypothesis of corn crops expansion in contrast to other crops is valid.

\section{CONCLUSIONS}

The dynamics of crop area under three main export-oriented crops (corn and sunflower) in three agro-climatic zones of Ukraine (Steppe, Forest Steppe, Polissya) in the 2000-2019 time horizon was investigated. The data from the State Statistics Service of Ukraine in the cross-section of 24 regions was used as information support. If the countrywide wheat area can be considered stable (variation is insignificant), with the exception of the extreme weather conditions in 2003, the corn and sunflower areas have grown steadily under the influence of increasing demand from national and world markets. At the same time, the growing acreage under corn and sunflower occurred in all climatic zones.

In the course of the study the differences of the yields of the studied crops in different agroclimatic zones were analyzed. On the basis of the use of the pairwise comparison of mean values apparatus, it was confirmed that for all three crops, the significance levels did not exceed 0.05 for wheat and 0.0001 for corn and sunflower, the yields in the Forest Steppe and Polissya areas were higher than in the Steppe zone. In addition, the analysis of yield differences in the Forest Steppe and Steppe zones revealed a stable statistically significant upward trend for all crops under study at a rate of 0.9 to 1.3 hundred $\mathrm{kg} / \mathrm{ha}$ per year.

The expansion of the main expo-oriented crops in each of the agro-climatic zones of Ukraine was analyzed. For this purpose, the concept of the middle latitude of the agro-climatic zone for each of the studied agricultural crop was used. The calculation technique was based on the determination of the middle weighted latitudes of the regional centers, of a certain 
agro-climatic zone with weights that were equal to the ratio of the area of a given crop in a given area to the total area of this crop in a certain agro-climatic zone.

The analysis revealed a steady expansion of the corn crop areas northward in all three natural climatic zones of Ukraine. This process is most stable in the Forest Steppe zone, where the annual northern expansion of crop spread is 0.0151 by latitudinal degree, or approximately $1.7 \mathrm{~km}$.

On the whole, we believe that the assumptions about a favorable influence on the development of the Ukrainian agricultural sector from the point of view of growing export-oriented crops are most likely to be confirmed. However, more favorable conditions are created in the Forest Steppe and Polissya zones, and this is confirmed by the increase in the yield differences in these zones, relative to the increase in yield in the Steppe zone. For the Steppe zone, the main challenge is the lack of wetlands and the problems associated with increasing aridity. Here, it will be necessary to grow more drought resistant varieties of crops, apply the moisture-saving technologies and develop the irrigation system.

As we expect a further increase in the air temperature, change in the humidity regime, increase in the frequency and intensity of extreme weather events, such changes will lead to a significant change in the agro-climatic resources of Ukraine. The research has shown that the boundaries of soil and climate zones will change and, as a consequence, the conditions for growing crops and their yield will alter, respectively. As a result of warming, the duration of the growing season will increase, the sums of temperatures during the $g$ rowing season will grow, whereas the lack of water to meet the needs of the plants will increase. Thus, the impact of weather conditions on the Ukrainian agriculture will be amplified, requiring the development of the measures to adapt and mitigate the negative impacts and exploit new potential opportunities that are being opened.

Therefore, despite the fact that a number of scientists around the world are studying the effects of climate change on all the spheres of human life, the task of efficient agriculture under such conditions requires a deeper study, as the agricultural sector is the most vulnerable link, which, in turn, provides a standard of living for the population and therefore requires urgent and adequate solutions.

\section{REFERENCES}

1. Adamenko, T. 2013. Climate change and its impact on Ukraine's agro-climatic resources. Presentation at the round table Development of agrarian production in the conditions of agroclimatic changes, Ukraine, Kyiv.

2. Amadu, F., McNamara, P. and Millera, D. 2020. Yield effects of climate-smart agriculture aid investment in southern Malawi. Food Policy. https://doi. org/10.1016/j.foodpol.2020.101869

3. Asfaw,S., Mccarthy, N., Lipper, L., Arslan, A. and Cattaneo A. 2016. What determines farmers' adaptive capacity? Empirical evidence from Malawi. Food Security, 8(3), 643-664. DOI:10.1007/ s12571-016-0571-0

4. Bokusheva, R. 2011. Measuring dependence in joint distributions of yield and weather variables, Agricultural Finance Review, 71(1), 120-141. DOI:10.1108/00021461111128192

5. Brechin1, S. 2003. Comparative public opinion and knowledge on global climatic change and the Kyoto Protocol: the US versus the world? International Journal of Sociology and Social Policy, 23(10), 106134. DOI:10.1108/01443330310790318

6. Chen, J., McCarl, B. and Thayer, A. 2017. Climate Change and Food Security: Threats and Adaptation. World Agricultural Resources and Food Security, 17, 69-84. DOI:10.1108/S1574-871520170000017006

7. Cogato, A., Meggio, F., Migliorati, M. and Marinello, F. 2019. Weather Events in Agriculture: A Systematic Review. Sustainability, 11(9), 2547. DOI:10.3390/su11092547

8. Cohen, J.1997. How many people can the Earth support? New York, NY.

9. Coulibaly, J.Y.,Chiputwa, B., Nakelse, T. and Kundhlande, G. 2017. Adoption of agroforestry and its impact on household food security among farmers in Malawi. Agric. Syst., 155, 52-69

10. Didukh,Y. 2009. Ecological aspects of the global climate changes: reasons, consequences and actions. Visnyk of the National Academy of Sciences of Ukraine, 2, 34-44.

11. Dittrich, R., Wreford, A. and Moran, D. 2016. A survey of decision-making approaches for climate change adaptation: are robust methods the way forward? Ecological Economics, 122, 79-89. DOI:10.1016/j.ecolecon.2015.12.006

12. FAO 2017. The State of Food Security and Nutrition in the World 2017: Building Resilience for Peace and Food Security, Italy, Rome.

13. Gobin, A., Tarquis, A. and Dalezios, R. 2013. Weather-related hazards and risks in agriculture. Natural Hazards and Earth System Science, 13(10), 2599-2603. DOI:10.5194/nhess-13-2599-2013 
14. Imelda, I., Matthias, F. and Michael, J. Roberts. 2018. Variable Pricing and the Cost of Renewable Energy. National Bureau of Economic Research Working Papers, 24712.

15. IPCC. 2014. IPCC's Fifth Assessment Report (WGII AR5) Climate Change (2014), Impacts, Adaptation, and Vulnerability. available at: http://www.ipcc.ch/ report/ar5/wg2

16. IPCC. 2018. Intergovernmental Panel on Climate Change, Global warming of $1.5^{\circ} \mathrm{C}$ : an IPCC special report on the impacts of global warming of $1.5 \mathrm{C}$ above pre-industrial levels and related global greenhouse gas emission pathways, in the context of strengthening the global response to the threat of climate change, sustainable development, and efforts to eradicate poverty, available at: http://www.ipcc.ch/report/sr15/ .

17. Kadiyevskyy, V. and Klymenko, N. 2014. Systemic vision of ecological and economic interaction of landuse factors in modern agrosphere. Actual Problems of Economics, 152(2), 313-320.

18. Kalenska, S., Yeremenko, O., Novictska, N., Yunyk A., Honchar, L., Cherniy, V., Stolayrchuk, T., Kalenskyi, V., Scherbakova, O., and Rigenko, A. 2019. Enrichment of field crops biodiversity in conditions of climate changing. Ukrainian Journal of Ecology, 9 (1), 19-24.

19. Kassie, M., Teklewold, H., Jaleta, M., Marenya, P. and Erenstein, O. 2015.Understanding the adoption of a portfolio of sustainable intensification practices in eastern and southern Africa. Land Use Policy, 42, 400-411. DOI:10.1016/j.landusepol.2014.08.016

20. Lal Pandey, C. 2014. The limits of climate change agreements: from past to present. International Journal of Climate Change Strategies and Management, 6(4), 376-390. DOI:10.1108/ IJCCSM-03-2013-0026

21. Morison, J.1996. Climate change and crop growth. Environmental Management and Health, 7(2), 4-27. DOI:10.1108/09566169610112980

22. Müller, C., Cramer, W., Hare, W.L.and LotzeCampen, H. 2011.Climate change risks for African agriculture. Proc. Natl. Acad. Sci., 108 (11), 43134315. DOI:10.1073/pnas.1015078108

23. Nechyporenko, O. 2016. Status and prospects of the Ukrainian economy's agricultural sector adaptation to global climate changes. Ukrainian journal Economist, 11, 10-14.

24. Noltze, M., Schwarze, S. and Qaim M. 2013. Understanding the adoption of system technologies in smallholder agriculture: the system of rice intensification (SRI) in Timor Leste. Agricultural Systems, 108, 64-73. DOI:10.1016/j.agsy.2012.01.003

25. Ollila, A. 2019. Challenging the scientific basis of the Paris climate agreement. International Journal of Climate Change Strategies and Management, 11(1), 18-34. DOI:10.1108/IJCCSM-05-2017-0107
26. Pace, C. 2015. Genomic tools and plant genes to mitigate impacts of climate change and extreme environments. Holistic Access to Research on Vegetables, Economies, Societies and Technology, 10, 553-568.

27. Panasiuk, B. 2015. Global climate change and the economy. Ekonomika APK, 11, 14-24, available at: http://eapk.org.ua/contents/2015/11/14

28. Passel, S., Massetti E., Mendelsohn, R. 2017. Aricardian analysis of the impact of climate change on European agriculture. Environmental and Resource Economics, 67, 725-760. DOI:10.1007/s10640-016-0001-y

29. Prokopenko, K. and Udova, L. 2017.Ukrainian agriculture: challenges and ways of development under the climate change. Economy and Forecasting, 1, 92104, available at: eip.org.ua > docs > EP_17_1_92_uk.

30. Ren, Z. and Lin, Y. 2001. Global warming and its astro-causes. Kybernetes, 30(4), 411-433. DOI: $10.1108 / 03684920110386928$

31. Report OCHA.2019. Natural Disasters in Latin America and the Caribbean, 2000-2019, available at: https://reliefweb.int/sites/reliefweb.int/files/ resources/20191203-ocha-desastres_naturales.pdf

32. Rosenzweig, C., Iglesias, A., Yang, X.B., Epstein, P.R. and Chivian, E. 2001. Climate change and extreme weather events: Implications for food production, plant diseases, and pests. Glob. Change Hum. Health, 2, 90-104. DOI:10.1023/A:1015086831467

33. Rudych, O. 2018. Natural and climatic conditions as a risk factor for agricultural production in Ukraine. Sustainable Development of Economy, 2(39), 14-21.

34. Selvaraju, R, Gommes, R. and Bernardi, M. 2011. Climate science in support of sustainable agriculture and food security. Climate Research, 47(1-2), 95-110. DOI: $10.3354 / \mathrm{cr} 00954$

35. Shannon R. and Motha, P.2015. Managing weather and climate risks to agriculture in North America, Central America and the Caribbean. Weather and Climate Extremes, 10(A), 50-56. DOI:10.1016/j. wace.2015.10.006

36. Siwiec, E. 2015. Losses and expenditures caused by extreme events in Poland. Disaster Prevention and Management, 24(5), 553-569. DOI:10.1108/ DPM-03-2014-0047

37. Skrypnyk, A., Klymenko, N., Talavyria, M., Goray, A. and Namiasenko, Y.2019. Bioenergetic potential assessment of the agricultural sector of the Ukrainian economy. International Journal of Energy Sector Management, 14 (2), 468-481. DOI:10.1108/ IJESM-04-2019-0015

38. SSC. 2018. Agriculture of Ukraine. Statistical collection of State Statistics Service of Ukraine, Kyiv, available at: www.ukrstat.gov.ua

39. Tesfahun, W. 2018.Climate change mitigation and adaptation through biotechnology approaches: A 
review. Cogent Food and Agriculture, 4, 1-12. DO I:10.1080/23311932.2018.1512837

40. Tsytsyura, Y.2017. Adaptive strategy of agriculture of the right-bank Ukrainian forest-steppe in the conditions of climate change. Agriculture and Forestry, 5, 25-33.

41. Tun Oo, A., Van Huylenbroeck, G. and Speelman, S. 2017. Determining factors for the application of climate change adaptation strategies among farmers in Magwe District, dry zone region of Myanmar. International Journal of Climate Change Strategies and Management, 9(1), 36-55. DOI:10.1108/ IJCCSM-09-2015-0134

42. Voronenko, I., Skrypnyk, A., Klymenko, N., Zherlitsyn, D., and Starychenko, Y. 2020. Food security risk in Ukraine: assessment and forecast. Agricultural and Resource Economics: International Scientific E-Journal, 6(4), 63-75. DOI:10.51599/ are.2020.06.04.04
43. World Economic Forum.2 018 The Global Risks Report 2018 (13th ed.), World Economic Forum, Geneva, available at: https:/www.weforum.org/ reports/the-global-risks-report-2018

44. Xiong W., Holman I.P., Lin E., Conway D., Li Y. and $\mathrm{Wu}$ W. 2012.Untangling relative contributions of recent climate and $\mathrm{CO} 2$ trends to national cereal production in China. Environmental Research Letters, 7(4), 14-44. DOI:10.1088/1748-9326/7/4/044014

45. York, R., Rosa, E. and Dietz, T. 2003. A rift in modernity? assessing the anthropogenic sources of global climate change with the STIRPAT model. International Journal of Sociology and Social Policy, 23(10), 31-51. DOI:10.1108/01443330310790291

46. Zhou, S., Zhou, W., Lin, G., Chen, J., Jiang, T. and Li, M. 2017. Adapting to climate change: scenario analysis of grain production in China. China Agricultural Economic Review, 9(4). DOI:10.1108/ CAER-10-2016-0173 